\title{
PECULARITIES OF STRENGTH ASSESSMENT OF CAST-IN-SITU STRUCTURES IN
} TERMS OF SIBERIA

\author{
Endzhievskaya I. G. ${ }^{1, a}$, Kalugin I. G. ${ }^{2, b}$, Deygraf S. O. ${ }^{3, c}$, Galkin M. A. ${ }^{4, d}$ \\ ${ }^{1,2,3,4}$ Russia, 660041, Krasnoyarsk, Siberian Federal University, Svobodny prospect, 79 \\ a $\underline{\text { icaend@mail.ru, }},{ }^{\mathrm{b}} \underline{2828450 @ \text { mail.ru, }}{ }^{\mathrm{c}}$ Cergei_d@mail.ru,${ }^{\mathrm{d}}$ gal.makcim2014@yandex.ru
}

Keywords: cast-in-situ construction, climatic conditions of Siberia and the Far East, concrete strength, non-destructive method.

Abstract: This article states the results of experimental studies to assess concrete strength in cast-in-situ structures based on a systematic approach, including integrated research methods at all stages of construction of reinforced concrete structures. It was established that the concrete strength of the sample-cubes made on the object simultaneously with the structure and stored under the same conditions was slightly lower than the structures and standard control samples. The decrease in the strength of concrete samples from structures is on average 13,3\%. Its value is effected by several factors, one of the main was the maintenance of the structure. The most appropriate is to meet the requirements of achieving $70 \%$ of the design strength and higher percentage is required for cast-in-situ construction in terms of winter pouring concrete. At the same time, along with the assessment of the physical and mechanical properties of the structure by non-destructive methods, it is necessary to carry out tests aimed at determining the actual concrete strength based on samples made in the batching plant laboratory and solidified (cured) in permissible humidity conditions (herein after referred as PHC).

\section{Introduction}

Today cast-in-situ construction is the most mobile, flexible and cost-effective. It is the reason why the world volume of it reaches $55 . .80 \%$. An important problem of cast-in-situ construction technology in Russia is the task of increasing of the construction growth and resource [1].

Some special problems of pouring concrete of cast-in-situ reinforced concrete structures appear in cold seasons. There is a necessity to accelerate the concrete strength development at low temperatures. During the initial period of solidification the structures should be protected from freezing, precipitation or moisture loss, i.e. permissible humidity conditions (PHC) are to be maintained that can provide a stable increase in strength $[2,3]$.

It is extremely important to ensure the stripping concrete strength in terms of the climatic conditions of Siberia and the Far East, i.e. the modes of structures heating should be observed. One of the important stages of cast-in-situ building elements construction is the curing of concrete until the required strength is achieved. With the temperature rise during heating at the initial stage of solidifying, the chemical activity of water increases that results in the acceleration of solidifying. With the temperature drop freezing water increases in volume that results in a damage of the concrete structure; a significant decrease in its physical and technical properties and its strength, frost resistance and water resistance [4].

Some other mistakes that can result in the decrease of properties are as follows:

- flow concrete contains much more water than it is required for hydration (mixing) of cement that leads to the formation of directed concrete porosity due to the release of free moisture. In cast-in-situ works most organizations give priority to workability. As a rule, there is an overstated water grade, but the control over the concrete fluidity is not provided.

- when pouring concrete of massive structures, there are some typical damages to the structure. It happens because some areas are not consolidated. After solidification some cracks are formed. They pass along the bonding lines of different concrete areas - both in vertical and horizontal direction. In the process of mixture layering the adhesion of fresh concrete to the solidified concrete is not provided. 
- the upper layer has the lowest density and the highest fluidity, it results in the decrease of strength. When shrinking structures, especially horizontal ones, the structure of the upper layer is significantly different in quality from the main array, which is denser due to the increased grade of fillers. There appear vertical and horizontal cracks with the delamination from the denser lower layers. Therefore, a low water-cement ratio is an important requirement to avoid inhomogeneity in composition and structure in thickness[5,6,7].

\section{Relevance of the issue with a brief review of literature}

The cast-in-situ structures construction is a complex and diverse process, especially in terms of long low temperatures. The quality of concrete plays the most important role as it ensures durability.

The difficulty of winter pouring concrete is to ensure a positive temperature of the concrete for the period of time that is necessary to develop strength. At this strength the necessary resistance to the pressure of the ice formed and the ability for further solidifying at positive temperatures without a noticeable decrease in strength and other properties are provided.

At present, the results of cryological studies of concrete are not sufficiently analyzed, some of them are aimed at accelerating the concrete solidifying by means of chemical admixtures $[8,9]$. As a result, it contributes to reducing the time required for the concrete to develop a critical strength. Some combinations of the use of chemical admixtures of both solidifying accelerators and heat supply to concrete from outside have been studied [10]. The issues of cast-in-situ concrete quality improvement by multifrequent hypersonic activation of gauging water [11] and mechanical activation of cements [12] have been considered.

The kinetics of plasterless cement systems solidifying at low temperatures is presented in works [13]. Some methods of pouring concrete at low temperatures [14, 15], new technologies of electric heating [16], and an impact of air-entraining and mineral admixtures on frost resistance [17] have been studied.

Unfortunately, a huge number of surveys results of reinforced concrete structures both raised and in operation in large industrial enterprises that has been held recently in northern parts of Russia is poorly analyzed. Meanwhile, a systematic assessment of the data would contribute to the objective clarification and justification of requirements for quality and durability of both concrete and reinforced concrete. Due to the increased requirements for timing and quality of construction, the issues of ensuring the design strength properties of reinforced concrete structures are becoming increasingly important.

Therefore, the research is aimed at assessing the strength of cast-in-situ structures based on a systematic approach that includes integrated research methods for determining the characteristics at all stages of construction.

\section{Theory}

The authors have been carrying out the laboratory quality control at large construction sites for a long time. The concrete strength of sample-cubes was determined by destructive methods. The sample-cubes were made by the batching plant laboratory and at the construction site from the delivered concrete. Also, the strength was determined when solidifying in structure by nondestructive methods both direct and indirect [18]. If the strength is lower than the project of works for concrete of a given age requires, the reason for the deviation is found (for example, insufficient consolidation, improper cure of concrete or temperature and humidity conditions of strength development).

When controlling the strength by destructive methods it is difficult to determine which samples have the greatest approximation in terms of values reliability, whether they were made in the laboratory or at the site along with the structure and stored in the same conditions. Several factors that effect the strength indicators are as follows:

- the presence of a vibration platform in the batching plant laboratory and a greater homogeneity in consolidation. It is confirmed by the values of a variation coefficient.

- the conditions of concrete solidifying in structures and forms with sample-cubes stored in a similar environment differ from the permissible humidity conditions (PHC) and are less 
favorable to concrete. As the scales of sample and structure differ significantly so the processes of structure formation of cement system will proceed differently [19].

The strength control by non-destructive methods is carried out on the surface of structure, so the state of the upper layer can have a significant effect on the results of the control. They usually differ from internal concrete.

The factors that effect the measurement inaccuracy in the control and assessment of concrete strength by non-destructive methods are inhomogeneity of the concrete materials in the sample volume; under-compacted and over-vibrated sections of structure; the disintegration of flow concrete; surface defects; corrosion and carbonation of upper layer. The faults of a device are considered as well. They are a spring wear or a weak battery charging especially at low temperatures. In addition, the parameters of concrete at site may differ significantly from those that the calibration curve was built at. It reduces the reliability of the strength values [20].

The removal of samples from cast-in-situ body is a quite informative way to assess the strength of concrete structures. The samples are tested further. However, any sawing or drilling in concrete causes local defects, even without taking into account the fact that this method is quite expensive and time-consuming[21].

Thus, the production and technological factors have a rather complex effect on the determination of the average concrete strength and explain the result of any particular test. Therefore, along with the control of all major technological processes in terms of their stability on the specified parameters, it is necessary to check constantly the quality of concrete by an independent laboratory with several methods including the processing of results based on statistic dependencies. The analysis of data allows to maintain the concrete quality at a consistently high level [22].

The statistic control of homogeneity and concrete strength allows to determine the average values of strength in relation to specified values that can be taken in the production of concrete works depending on the achieved coefficient of variation. The systematic determination of statistic characteristics at a particular construction site gets an idea of the degree of placed concrete homogeneity and the adjustment of the technological process as a whole. [23].

\section{The experiment results}

One of the most important problems of determining the cast-in-situ concrete strength in the northern regions by non-destructive methods is a long (more than 5 months) period with low temperatures, when the outside air temperature is below $-10^{0}$ C. However, according to all-Union State Standard 22690-2015, non-destructive testing methods may be carried out at a temperature not lower than- $10^{0} \mathrm{C}$ in terms of established calibration curve. If the concrete tests by non-destructive methods are not possible by the end of the heating (the determination of stripping strength) at an outside temperature less than- $25^{\circ} \mathrm{C}$. At this temperature concrete has been cooling to $-10^{\circ} \mathrm{C}$ for $24-36$ hours. Testing by all-Union State Standard under such conditions is prohibited, but often further construction work depends on the possibility of structure loading. Therefore, it is necessary to have experimental calibration curve. Table 1 shows the comparison between strength determining data of 28-days-old concrete grades $\mathrm{B} 15$ and B25 in summer at a temperature of $+20 \pm 3^{\circ} \mathrm{C}$ (table 1) and the concrete of the same grades of winter compositions that solidified at low temperatures below $-10^{0} \mathrm{C}$ (tables 2 and 3 ) [24].

Table 1. The results of the control tests of concrete grades B15 and B25 at a temperature of +20 $\pm 3^{0} \mathrm{C}$

\begin{tabular}{|c|c|c|c|c|}
\hline \multirow[b]{3}{*}{$\frac{\mathscr{d}}{\stackrel{d}{J}}$} & \multicolumn{4}{|c|}{ Concrete strength values, MPa, defined by means of } \\
\hline & \multicolumn{2}{|c|}{ Grade B15 } & \multicolumn{2}{|c|}{ Grade B25 } \\
\hline & $\begin{array}{l}\text { Destructive method } \\
\text { modeled upon cubes }\end{array}$ & $\begin{array}{l}\text { Non-destructive method } \\
\text { in the structure }\end{array}$ & $\begin{array}{c}\text { Destructive } \\
\text { method modeled } \\
\text { upon cubes }\end{array}$ & $\begin{array}{l}\text { Non-destructive } \\
\text { method in the } \\
\text { structure }\end{array}$ \\
\hline
\end{tabular}




\begin{tabular}{|c|c|c|c|c|c|c|c|c|}
\hline & $\begin{array}{l}\text { In the } \\
\text { batching } \\
\text { plant } \\
\text { labora- } \\
\text { tory }\end{array}$ & In-situ & $\begin{array}{l}\text { indirect } \\
\operatorname{CST}\left(\mathrm{H}_{\mathrm{i}}\right)\end{array}$ & $\begin{array}{c}\text { Direct } \\
\text { Shear test } \\
\quad\left(\mathrm{R}_{\mathrm{i \phi}}\right)\end{array}$ & $\begin{array}{l}\text { In the } \\
\text { batching } \\
\text { plant } \\
\text { labora- } \\
\text { tory }\end{array}$ & In-situ & $\begin{array}{c}\text { Indirect } \\
\operatorname{CST}\left(\mathrm{H}_{\mathrm{i}}\right)\end{array}$ & $\begin{array}{c}\text { Direct } \\
\text { Shear } \\
\text { test } \\
\left(\mathrm{R}_{\mathrm{i} \phi}\right)\end{array}$ \\
\hline \multirow{5}{*}{ 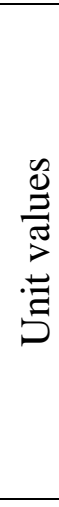 } & $\begin{array}{l}21,6 \\
22,3\end{array}$ & $\begin{array}{l}24,0 ; \\
21,7\end{array}$ & $\begin{array}{c}22,8 ; 23,0 \\
23,6 ; 23,9\end{array}$ & 21,9 & $\begin{array}{l}32,7 \\
34,8\end{array}$ & $\begin{array}{l}32,3 \\
35,5\end{array}$ & $\begin{array}{l}36,2 ; 32,6 ; \\
35,3 ; 36,0\end{array}$ & 34,1 \\
\hline & $\begin{array}{l}24,1 \\
20,9\end{array}$ & $\begin{array}{l}22,6 \\
21,4\end{array}$ & $\begin{array}{l}23,7 ; 24,4 ; \\
22,0 ; 20,1\end{array}$ & 21,9 & $\begin{array}{l}32,3 ; \\
33,0\end{array}$ & $\begin{array}{l}31,9 \\
32,9\end{array}$ & $\begin{array}{l}33,4 ; 31,8 ; \\
35,1 ; 32,9\end{array}$ & 34,9 \\
\hline & $\begin{array}{l}22,8 ; \\
21,8\end{array}$ & $\begin{array}{r}23,4 ; \\
19,5\end{array}$ & $\begin{array}{l}23,0 ; 22,6 ; \\
23,3 ; 23,1\end{array}$ & 22,9 & $\begin{array}{l}34,7 ; \\
36,1\end{array}$ & $\begin{array}{l}32,3 \\
36,8\end{array}$ & $\begin{array}{l}37,2 ; 35,9 \\
36,8 ; 40,1\end{array}$ & 36,6 \\
\hline & $\begin{array}{l}20,9 ; \\
22,7\end{array}$ & $\begin{array}{l}19,8 ; \\
22,7\end{array}$ & $\begin{array}{l}19,8 ; 19,4 ; \\
24,2 ; 23,7\end{array}$ & 22,5 & $\begin{array}{l}34,6 ; \\
35,1\end{array}$ & $\begin{array}{l}31,9 \\
35,2\end{array}$ & $\begin{array}{l}38,1 ; 37,5 ; \\
39,3 ; 37,2\end{array}$ & 35,2 \\
\hline & $\begin{array}{l}23,0 ; \\
24,2\end{array}$ & $\begin{array}{r}23,9 ; \\
19,5 \\
\end{array}$ & $\begin{array}{l}22,4 ; 23,6 ; \\
25,0 ; 25,3\end{array}$ & 23,3 & $\begin{array}{l}35,6 ; \\
32,6\end{array}$ & $\begin{array}{l}34,9 \\
36,7 \\
\end{array}$ & $\begin{array}{l}36,6 ; 36,2 ; \\
37,1 ; 39,4\end{array}$ & 36,3 \\
\hline 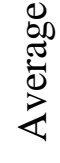 & 22,4 & 21,9 & 23,2 & 22,0 & 34,2 & 34,0 & 36,2 & 35,5 \\
\hline * & 5,20 & 8,07 & 8,55 & 7,35 & 4,02 & 5,83 & 7,17 & 5,38 \\
\hline \multicolumn{3}{|c|}{ Compensation coefficient } & 0,81 & & & & 0,76 & \\
\hline \multicolumn{3}{|c|}{ coefficient a } & 0,76 & & & & 0,49 & \\
\hline \multicolumn{3}{|c|}{ coefficient $b$} & 4,9 & & & & 16,5 & \\
\hline
\end{tabular}

v - coefficient of variation

Table 2. The results of the control tests of concrete grades B15 and B25 at a temperature of $-10{ }^{\circ} \mathrm{C}$

\begin{tabular}{|c|c|c|c|c|c|c|c|c|}
\hline \multirow[b]{4}{*}{ 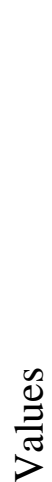 } & \multicolumn{8}{|c|}{ Concrete strength values, $\mathrm{MPa}$, defined by means of } \\
\hline & \multicolumn{4}{|c|}{ Grade B15 } & \multicolumn{4}{|c|}{ Grade B25 } \\
\hline & \multicolumn{2}{|c|}{$\begin{array}{l}\text { Destructive method } \\
\text { modeled upon cubes }\end{array}$} & \multicolumn{2}{|c|}{$\begin{array}{l}\text { Non-destructive method } \\
\text { in the structure }\end{array}$} & \multicolumn{2}{|c|}{$\begin{array}{c}\text { Destructive } \\
\text { method modeled } \\
\text { upon cubes }\end{array}$} & \multicolumn{2}{|c|}{$\begin{array}{l}\text { Non-destructive method } \\
\text { in the structure }\end{array}$} \\
\hline & $\begin{array}{c}\text { In the } \\
\text { batching } \\
\text { plant } \\
\text { labora- } \\
\text { tory }\end{array}$ & In-situ & $\begin{array}{c}\text { indirect } \\
\text { CST }\left(\mathrm{H}_{\mathrm{i}}\right)\end{array}$ & $\begin{array}{c}\text { Direct } \\
\text { shear test } \\
\left(\mathrm{R}_{\mathrm{i} \phi}\right)\end{array}$ & $\begin{array}{l}\text { In the } \\
\text { batching } \\
\text { plant } \\
\text { labora- } \\
\text { tory }\end{array}$ & In-situ & $\begin{array}{c}\text { indirect } \\
\text { CST }\left(\mathrm{H}_{\mathrm{i}}\right)\end{array}$ & $\begin{array}{c}\text { Direct } \\
\text { shear test } \\
\left(\mathrm{R}_{\mathrm{i \phi}}\right)\end{array}$ \\
\hline \multirow{5}{*}{ 导 } & $\begin{array}{l}23,0 \\
21,9\end{array}$ & $\begin{array}{l}13,6 ; \\
15,1\end{array}$ & $\begin{array}{c}16,2 ; 16,7 ; \\
19,1 ; 18,4\end{array}$ & 15,0 & $\begin{array}{l}33,0 \\
33,8\end{array}$ & $\begin{array}{l}23,9 \\
26,4\end{array}$ & $\begin{array}{l}29,8 ; 28,7 \\
31,1 ; 30,7\end{array}$ & 26,4 \\
\hline & $\begin{array}{l}23,2 \\
21,8\end{array}$ & $\begin{array}{c}15,8 ; \\
16,3\end{array}$ & $\begin{array}{c}16,5 ; 18,7 \\
17,9 ; 18,4\end{array}$ & 16,4 & $\begin{array}{l}31,9 ; \\
32,5\end{array}$ & $\begin{array}{l}27,1 \\
28,4\end{array}$ & $\begin{array}{l}32,1 ; 32,5 ; \\
34,0 ; 32,5\end{array}$ & 25,9 \\
\hline & $\begin{array}{l}22,5 \\
22,9\end{array}$ & $\begin{array}{l}14,4 \\
12,9\end{array}$ & $\begin{array}{c}15,7 ; 15,8 \\
15,9 ; 16,3\end{array}$ & 15,8 & $\begin{array}{l}34,7 ; \\
35,1\end{array}$ & $\begin{array}{l}25,3 \\
24,4\end{array}$ & $\begin{array}{l}30,1 ; 28,6 ; \\
29,4 ; 27,5\end{array}$ & 25,4 \\
\hline & $\begin{array}{l}21,0 \\
22,3\end{array}$ & $\begin{array}{c}14,7 \\
15,2\end{array}$ & $\begin{array}{c}16,0 ; 16,4 \\
18,3 ; 18,9\end{array}$ & 15,3 & $\begin{array}{l}36,6 ; \\
35,1\end{array}$ & $\begin{array}{l}23,9 \\
24,9\end{array}$ & $\begin{array}{l}26,5 ; 25,9 \\
26,7 ; 28,4\end{array}$ & 27,5 \\
\hline & $\begin{array}{l}24,0 ; \\
23,2\end{array}$ & $\begin{array}{c}16,9 ; \\
16,6\end{array}$ & $\begin{array}{c}19,1 ; 18,6 ; \\
17,6 ; 18,2\end{array}$ & 16,1 & $\begin{array}{l}34,7 ; \\
36,0\end{array}$ & $\begin{array}{l}22,8 \\
23,7\end{array}$ & $\begin{array}{l}26,7 ; 28,3 ; \\
29,4 ; 29,2\end{array}$ & 27,2 \\
\hline
\end{tabular}




\begin{tabular}{|c|c|c|c|c|c|c|c|c|}
\hline $\begin{array}{l}\bar{\sigma} \\
\bar{U} \\
\end{array}$ & 22,6 & 15,1 & 17,4 & 15,7 & 34,3 & 25,1 & 29,4 & 26,5 \\
\hline$r$ & 5,82 & 8,56 & 9,26 & 7,10 & 4,42 & 6,94 & 8,63 & 6,19 \\
\hline \multicolumn{3}{|c|}{ Compensation coefficient } & 0,71 & & & & 0,90 & \\
\hline \multicolumn{3}{|c|}{ coefficient a } & 0,42 & & & & 0,47 & \\
\hline \multicolumn{3}{|c|}{ coefficient $b$} & 7,89 & & & & 11,51 & \\
\hline
\end{tabular}

Table 3. The results of the control tests of concrete grades B15 and B25 at a temperature of $-25^{\circ} \mathrm{C}$

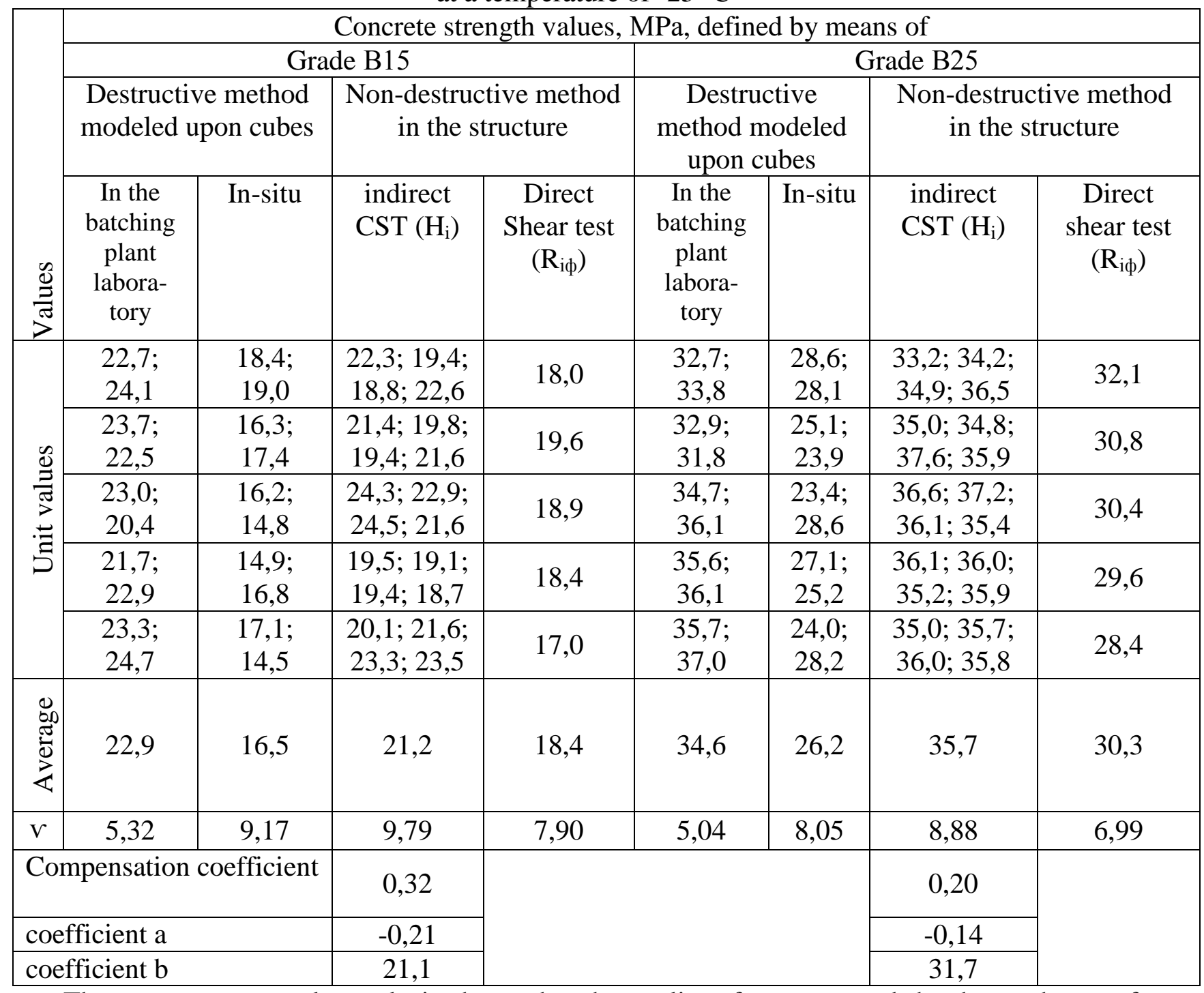

The average test results analysis shows that the quality of concrete and the thoroughness of control are good enough, since the coefficient of variation does not exceed $15 \%$.

The strength of concrete samples made of concrete at site simultaneously with the structure and stored under the same conditions was slightly lower than the strength of structures and standard control samples. This trend is recorded in the analysis of several objects of different Customers. The average decrease in strength of structures concrete samples is $13,3 \%$. Its value is effected by several factors. One of the main was the maintenance of the structure. Moreover, a smaller decrease in strength $-10,6 \%$ was observed for concretes of higher strength (B25), because they solidify faster and are less sensitive to temperature and humidity conditions. In addition, at lower temperatures there is an increase of the coefficient of variation when 
determining the strength, especially based on sample-cubes which are stored in similar conditions to structures.

\section{Conclusion}

According to the research it is the most reasonable to meet the requirement of achieving $70 \%$ or more of the structure strength for cast-in-situ construction in terms of winter pouring concrete at the time of structure stripping after heating. At the same time, along with the assessment of physical and mechanical properties of the structure by non-destructive methods, it is necessary to determine the actual concrete strength of control samples made in batching plant laboratory and solidified in permissible humidity conditions.

It should be noted that one of the main problems of determining the strength value of cast-insitu reinforced concrete structures by non-destructive methods in the Northern regions is the "design age". According to all-Union State Standard 18105, the actual concrete class should be determined after 28 days, unless there are no other terms in reference documents, such as work execution rules (WER). In practice, there are situations when laboratories require testing the 28days-old concrete, for example, the test should be carried out in January if pouring concrete takes place in December. In Siberia, low temperatures have been lasting for about five months or longer (below $-10^{\circ} \mathrm{C}$ ) and a concrete strength development after heating is actually impossible.

According to reference documents supervision agencies may require the builders to show the test reports with the compliance results (or non-compliance results) of the strength value to the design requirement at the age that was mentioned in January. However, in practice the concrete is not strong enough because of low temperatures. It is impossible to warm up the structure at the temperature of $20^{\circ} \mathrm{C}$ for $21-28$ days, because it is very energy-consuming. It significantly reduces the speed of buildings construction and results in increase of construction cost in winter. When the building is being constructed it is impossible to wait for constant high temperatures in order to achieve the design strength of the concrete. To ensure the continuity of the process builders have to carry out subsequent work, since the duration of the period is up to 4-6 months. However, with the continuous construction of structures many of them will not be available for strength determination by the time of positive temperatures.

So, the next stage of the research will be aimed at the determination of strength development speed of different concrete grades since melting time.

References

\section{References to papers}

[1] Sennikov. O.E. K vyboru metodik kontrolya kachestva monolitnogo betona / O.E. Sennikov. - N.Novgorod: NGASU. 2003. - S. 198-202.

[2] Sennikov O.E. K otsenke kachestva stroitelno-montazhnykh rabot v monolitnom domostroyenii / O.E. Sennikov. - N.Novgorod: NGASU. 2004. - S. 293-296.

[3] Sennikov O.E. O sozdanii kompleksnoy sistemy kachestva monolitnogo domostroyeniya / O.E. Sennikov. - N.Novgorod: NGASU. 2002. - S. 66-69.

[5] Sennikov O.E. Ob obespechenii kachestva monolitnogo domostroyeniya / O.E. Sennikov. - Vladimir. 2003. - S. 56-58.

[6] Sennikov O.E. Sovershenstvovaniye tekhnologii monolitnogo domostroyeniya putem avtomatizatsii tekhnologicheskikh protsessov / O.E. Sennikov. - Penza. 2004. - S. 90-92.

[8] Serdyukova. A.A. O mekhanizme deystviya uskoriteley skhvatyvaniya i tverdeniya tsementnoy matritsy betona / A.A. Serdyukova. I.Sh. Rakhimbayev // Vestnik Belgorodskogo gosudarstvennogo tekhnologicheskogo universiteta im. V.G. Shukhova. - 2013. - № 2 . - S. 26-28.

[9] Tolkynbayev. T.A. Dobavka dlya zimnego betonirovaniya monolitnykh sooruzheniy / T.A. Tolkynbayev. S.G. Golovnev. Sh.K. Torpishchev // Vestnik YuzhnoUralskogo gosudarstvennogo universiteta. Seriya: Stroitelstvo i arkhitektura. -2013 . - T. 13. № 2. - S. 34-37.

[10] Minakov. Yu.A. Upravleniye kinetikoy tverdeniya betona pri otritsatelnykh temperaturakh / Minakov Yu.A.. Kononova O.V.. Anisimov S.N.. Gryazina M.V. // 
Fundamentalnyye issledovaniya. - Penza: Izdatelskiy Dom "Akademiya Estestvoznaniya". 2013 -S. 307-311.

[11] Kudyakov A.I. Uluchsheniye kachestva tsementnogo kamnya putem mnogochastotnoy ultrazvukovoy aktivatsii vody zatvoreniya / A.I. Kudyakov. A.G. Petrov. G.G. Petrov. K.V. Ikonnikova // Vestnik Tomskogo gosudarstvennogo arkhitekturno-stroitelnogo universiteta. - 2012. - № 3 (36). - S. 143-152.

[12] Gurianov. G.A. Uluchsheniye protsessa prigotovleniya i kachestva betona na osnove analiza sposobov aktivatsii tsementa / G.A. Gurianov. E.A. Klimenko. O.Yu. Vasilyeva // Transport. Transportnyye sooruzheniya. Ekologiya. - 2015. - № 1. - S. 23-41.

[13] Cerdyukova. A. A.. Vliyaniye ponizhennykh temperatur na kinetiku tverdeniya tsementnykh sistem / A.A. Serdyukova. Sh.M. Rakhimbayev // Vestnik Belgorodskogo gosudarstvennogo tekhnologicheskogo universiteta im. V.G. Shukhova. - 2012. - № 3. - S. 4952.

[14] Osipov. A.M. Betonirovaniye pri nizkikh temperaturakh / A.M. Osipov // Inzhenernyy vestnik Dona. - 2012. - № 4-2 (23). - S. 161.

[15] Golovnev. S.G. Novyy sposob vozvedeniya monolitnykh zdaniy v zimneye vremya / S.G. Golovnev. A.Kh. Bayburin. L.A. Berkovich // Vestnik Yuzhno-Uralskogo gosudarstvennogo universiteta. Seriya: Stroitelstvo i arkhitektura. - 2010. - № 15 (191). - S. 5658 .

[16] Shelekhov. I.Yu. Primeneniye novykh tekhnologiy elektricheskogo nagreva v protsesse zimnego betonirovaniya / I.Yu. Shelekhov. E.I. Smirnov. V.P. Innozemtsev // Novaya nauka: Problemy i perspektivy. - 2015. - № 6-2. - S. 200-205.

[17] Kefeng Tan. Frost Resistance of Concrete with Different Strength Grades and Mineral Admixtures / Kefeng Tan // Modern Civil and Structural Engineering. - 2018. - Vol. 2. №. 1. - P. 1-9.

[18] Berbekov. Zh. V. Nerazrushayushchiye metody kontrolya prochnosti betona / Zh.V. Berbekov // Molodoy uchenyy. - 2012. - № 11. - S. 20-23.

[19] Evseyev. B.A. Proizvodstvo betonnykh rabot / B.A. Evseyev // Arkhitektura i stroitelstvo. - 2002. - № 10. - S. 27-32.

[20] Petrov. A. Tekhnologiya stroitelnogo proizvodstva/ A. Petrov // Stroitelnyy Ekspert. - 2003. - №6. - S. 29-33.

[21] Mkhitaryan. N. Novaya tekhnologiya $\mathrm{v}$ monolitnom domostroyenii / $\mathrm{N}$. Mkhitaryan. G. Badeyan. E. Malatsidze // Kapstroitelstvo. - 2002. - №5. - C. 9-12.

\section{References to manuscripts}

[4] Sennikov O.E. Sovershenstvovaniye metodov i sredstv tekhnologicheskogo kontrolya kachestva uplotneniya betonnoy smesi i prochnostnykh kharakteristik monolitnogo betona. Avtoreferat. / O.E. Sennikov. - N. Novgorod. 2005. - 25 s.

[7] Danilov. N.N. Tekhnologiya stroitelnykh protsessov: Uchebnik dlya vuzov / Pod obshch.red. N.N.Danilova. O.M.Terentyeva. - Moskva : Vysshaya shkola. 2005. - 464 s.

[22] Yunusov. N.V. Proyektirovaniye proizvodstva betonnykh rabot $\mathrm{v}$ zimneye vremya: Uchebnoye posobiye / N.V. Yunusov. A.B. Valt. S.G. Golovnev. - Chelyabinsk: ChPI. 2004. - $282 \mathrm{~s}$.

[23] ST-NP SRO SSK-03-2013 Pravila kontrolya i otsenki prochnosti betona monolitnykh konstruktsiy. - Vved. 16.04.2014. - Chelyabinsk: SROSSKUiS. 2013. - 13 s. 